Fast track opportunities for high achievers? A comparative investigation into career advancement patterns for in-house and consultancy practitioners 


\title{
Fast track opportunities for high achievers? - A comparative investigation into career advancement patterns for in-house and consultancy practitioners
}

\section{Katharina Wolf MPRIA MCIPR}

\section{Curtin University of Technology, Australia}

\begin{abstract}
Consultancy? Or in-house department? Public relations and communication graduates usually extensively debate the 'pro and cons' of the industry's two key employment options. However, to date there has been a lack of research into potential differences in required skills sets, career advancement and promotional opportunities between these two employment types. Contrary to management research, public relations scholars have largely focused on traditional career advancement determinants, such as experience in years and gender, largely failing to embrace modern management research into career advancement. Based on the author's previous research into alternative career advancement factors, which has highlighted the importance of social competencies and networking skills for PR practitioners, this paper sets out to investigate potential differences in career advancement factors and career development patterns for in-house and consultancy-based practitioners.
\end{abstract}




\section{About the author}

Katharina Wolf MCIPR MPRIA

is a lecturer in public relations at Curtin University of Technology, Perth, Western Australia, with experience in both corporate and consultancy practice. Katharina is an active member of the PRIA WA State Council and Chairperson of PRIA Young Guns, a sectorial group for young and emerging public relations practitioners in Western Australia. She is also a member of the Chartered Institute of Public Relations and holds a first class Honours degree in Media \& Communication Studies and Spanish Studies as well as a Master in Public Relations from Manchester Metropolitan University.

Katharina can be contacted at: $\underline{\text { k.wolf@ curtin.edu.au }}$ 


\section{Introduction}

Although public relations as a function, in terms of looking after one's reputation, has existed for centuries, is has only relatively recently developed into a recognised discipline. In contrast to traditional professions such as law or medicine, public relations research is still relatively young and has few strong theories. However, based on PR practitioner roles literature, such as Broom and Smith's (1979) 'pioneering' four role typology and Dozier's (1984) subsequent managertechnician dichotomy, research into career advancement factors has traditionally been one of the dominant themes within public relations literature. Public relations practitioners are usually either employed by an organisation's in-house department, or work within a consultancy (or agency). Nevertheless, with the exception of Toth et al.'s (1998) Agency Profile, developed over a decade ago, scholarly research has largely focused on in-house practitioners.

Despite the ongoing debate surrounding the professionalisation of public relations (Ehling, 1992; Pieczka \& L'Etang, 2006; Valin, 2005; Van Ruler, 2005; Wylie, 1994) and even the recent granting of a chartered status to the UK's Institute of Public Relations (now: Chartered Institute of Public Relations (CIPR)), the industry lacks a defined career route, outlining basic skills and qualifications to enter, as well as a guide stating how to advance a career within the field of public relations. The only established fact to date appears to be that PR is increasingly an allgraduate profession (Coppola, 2003; Singh \& Smyth, 2000). 
Public relations students frequently debate and compare career opportunities offered by in-house departments and consultancies. A graduate position in a consultancy or agency requires good time management and prioritising skills, as consultants "need to be able to juggle different accounts and learn quickly about a variety of companies and their markets" (Chartered Institute of Public Relations, 2008). As a result, a consultancy career is often perceived to be a good starting point to establish networks and contacts. In contrast to this, a career in a private, public or non-profit making organisation provides graduates with an opportunity to work exclusively for one organisation. This requires an in-depth knowledge of not only the organisation and its unique culture, but also the market it operates in.

This paper sets out to investigate possible differences in career advancement and required skill sets for practitioners working in these two key areas of employment.

\section{Literature}

Scholars have argued that public relations, in order to be truly effective and excellent, should be recognised as an integral part of an organisation's top management team and participate in strategic decision-making processes (Dozier \& Broom, 1995; Grunig \& Repper, 1992; White \& Dozier, 1992). However, the predominant focus of PR roles and career advancement research has traditionally been on gender issues and in particular on female discrimination (Moss \& Green, 2001; Moss, Warnaby, \& Newman, 2000), while widely ignoring career development factors increasingly stated in modern management literature; such as networking, personal traits, people 
skills, character and enthusiasm (Ishida, Su, \& Spilerman, 2002; Morgan, 2002). One exception is the research undertaken by Moss et al. (2000), DeSanto \& Moss (2004) and Moss, Newman, \& DeSanto (2005) into managerial behaviour in the public relations context, emphasising the crucial influence practitioners' relationship to (top) management may have on career advancement.

While the public relations industry is lacking academic research into career advancement models and influences, management scholars offer a wide range of academic research, which discuss models such as the 'seniority-based progression', the 'late-selection model' and the 'gatekeeping model' (Ishida et al., 2002). These findings arguably provide useful insight for the PR industry and could form the basis for future research into PR career advancement and frameworks.

\section{Changing working environments}

Mainstream management literature has emphasised that work environments have been undergoing dramatic changes. Two main developments have particularly impacted on the end of the traditional career ladder and resulted in global, changing demands for career advancement. First, the downturn in many Western economies has resulted in less job security (Cappelli, 2003; Morgan, 2002). Secondly, organisations have increasingly adopted flatter structures, which have resulted in downsizing, job insecurity and the lack of a clear career route (Holbeche, 2005; LipsWiersma \& Hall, 2007; Sahdev, Vinnicombe, \& Tyson, 1999). Across management literature there appears to be a general consensus that, while career advancement opportunities and the number of available positions have minimised on the one hand; criteria for professional advancement have tightened on the other (Ishida et al., 2002; Morgan, 2002). Experience is 
clearly no longer measured in time but in output. This phenomenon arguably applies particularly to the public relations industry, which is recognised as one of the top career choices amongst graduates (Keaveney, 2004). Consequently, the past decade has seen a worldwide 'explosion' of public relations focused degrees. Competition, particularly for entry level positions, is strong, with the average PR post advertised in the UK's Guardian receiving 300 applications (Coppola, 2003).

The employment landscape has changed. Arguably, with the exception of the public sector, there are no more guaranteed pay increases, promotions or career paths and most certainly "there is no more such thing like a 'Job for Life"' (Forsyth, 1998, preface). Research suggests that today's graduates, members of the so-called Generation Y, will change their jobs between 8-12 times during their working lives, including 3-4 complete career changes (Khare, 2007). In the late 1990s the Week-End Australian contacted education experts in a range of fields to estimate the shelf-life of Australian undergraduate degrees. Business degrees ranked in a mid-field with a shelf life of only four years (quoted in Burns, 2002), emphasising the increased focus on transferable skills, as well as the need for continuous professional development. As a result, traditional career advancement factors may have become increasingly replaced by a largely 'social skills'-focused set of competencies, such as networking, own initiative and continuous personal development (Gow \& McDonald, 2000; Ishida et al., 2002; Morgan, 2002).

The importance of personal qualities and social competencies, communication and listening skills, as well as an ability to work well as part of a team have been particularly emphasised within public relations literature (Cutlip, Center, \& Broom, 2005; James, 2006; Keaveney, 2004). Particularly, the ability to 'network' has traditionally been associated with public relations and 
communications related professions. However, despite employers' emphasis on enthusiasm, communication skills and social competencies in position descriptions and job advertisements, these factors have been largely ignored in academic research into the PR industry to date.

Career advice publications (James, 2006) and standard introductory textbooks (Cutlip et al., 2005; Newsom, Turk, \& Kruckenberg, 2007) discuss work in consultancies and in-house department as the two key PR career paths. However, public relations research has largely failed to investigate any potential differences in required skill sets and career development patterns. PR textbooks emphasise changing and increasing demands for practitioners, which the author's earlier research confirmed, highlighting that a public relations degree alone will not set graduates apart from other industry entrants (Wolf, 2006). Based on UK practitioners' perception, her research emphasised an alternative set of career advancement factors, highlighting the importance of social competencies and particularly networking skills, in addition to technical abilities. Respondents ranked "traditional" career advancement factors, such as gender, years of experience and relevant industry qualifications as neutral factors, while emphasising the need for a strong personality, enthusiasm and networking skills at all levels as necessity to move into, up and ahead in the field of public relations. Based on these findings and Morgan's (2002) 'Holistic Career Pyramid Model', Wolf (2006) developed the Five-Step Career Progression Model (Figure 1), emphasising that "while the model does not set out to imply tasks, responsibilities and pay scales for all practitioners working at the same level are identical, it may act as a useful starting point (....) towards a widely accepted set of career progression benchmarks for the PR industry" (p. 184). 


\section{Figure 1: Five-Step Career Progression Model (Wolf, 2006)}

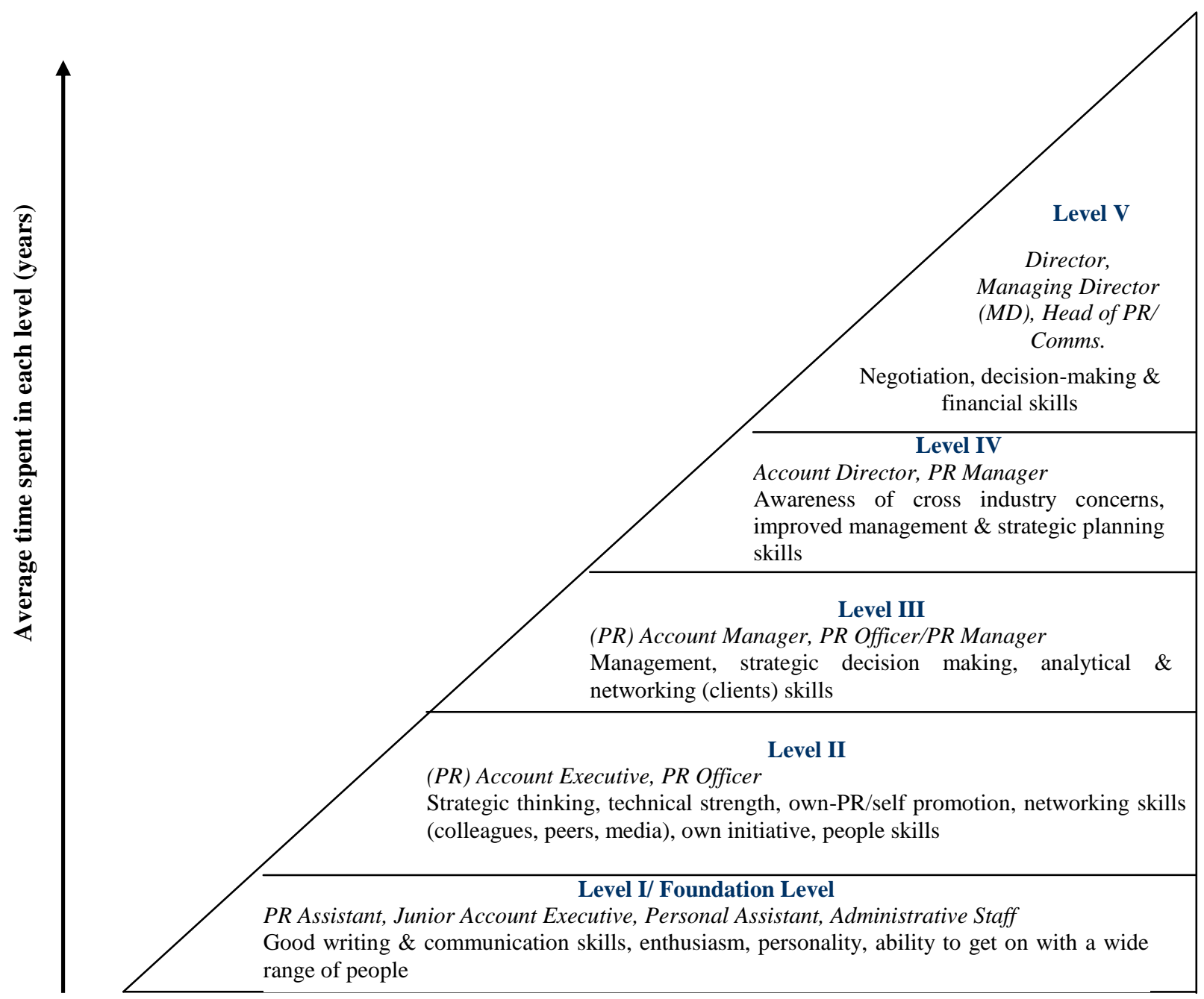

Evolution of skills and role

\section{Data collection}

This study is part of a larger research project, investigating career advancement determinants and patterns, based on semi-structured interviews, followed by a survey questionnaire. The Chartered Institute of Public Relations (CIPR) in the UK is the biggest association in Europe and arguably the second best known after the Public Relations Society of America (PRSA) (Ehling, 1992; Van 
Ruler, 2005). Consequently, the United Kingdom was selected as a well advanced and developed industry, which might provide valuable insight before expanding the scope of the study. Although the author recognises that these results are country specific, they may nevertheless provide a benchmark for further research into career advancement patters for public relations practitioners in other geographical areas.

Questionnaires, investigating practitioners' perception of career advancement determinants, were distributed to 640 UK-based PR professionals, equally distributed between in-house departments and consultancies. Practitioners were chosen randomly from a cross-section of the UK's public relations industry, focusing primarily on CIPR members. The 34-question survey combined closed and open ended questions, based on career advancement factors emphasised in general management and career development literature, while furthermore considering traditional advancement factors, as discussed in public relations research to date. Respondents were asked to rate the importance of traditional and new factors on a five-point Likert-style rating scale, ranging from 1 (not important at all) to 5 (very important).

\section{Findings}

Responses were collected from 73 consultancy-based and 78 in-house PR practitioners, which equals a usable response rate of $22 \%$. Overall, the data indicated that career progression for consultancy practitioners may be more straightforward and systematic than for their in-house counterparts. In-house practitioners appear to be struggling with a wide range of interchangeable and often not universally recognised titles, including 'unique' labels such as 'Policy and Public 
Affairs Officer', 'National Development Manager', 'Communications Team Leader', 'External Relations Executive' and 'Customer Relations Manager'. Furthermore, data indicated that inhouse staff may frequently be limited by the small or micro size of their department and the resulting lack of promotional opportunities. In contrast to this, consultancy staff appears to benefit from increasingly globally recognised promotional patterns as stated both by the CIPR and the Public Relations Consultants Association (PRCA): (Junior/Senior) Account Executive (Senior) Account Manager-Account Director-Managing Director.

However, the overall results and reported perceptions by both employment groups were broadly in line. Consultancy and in-house responses were compared to the original overall mean of Wolf's (2006) 18 Perceived Career Influencing Factors (see Table 1). Despite in-house practitioners rating their relationship to top management slightly higher, while consultancy staff particularly emphasised the importance of networking with clients and journalists, the overall ranking by median and order of perceived career influencing factors remains largely unchanged for both employment groups. 
Table 1: Perceived Career Influencing Factors

\begin{tabular}{|c|c|c|c|c|c|}
\hline & $\begin{array}{l}\text { Career Influencing } \\
\text { Factor }\end{array}$ & $\begin{array}{c}\text { overall } \\
\text { rating }\end{array}$ & $\begin{array}{l}\text { Original } \\
\text { overall } \\
\text { mean }\end{array}$ & $\begin{array}{l}\text { consult } \\
\text { ancy } \\
\text { mean }\end{array}$ & $\begin{array}{l}\text { in- } \\
\text { house } \\
\text { mean }\end{array}$ \\
\hline 1 & $\begin{array}{l}\text { Strong personality \& } \\
\text { enthusiasm }\end{array}$ & $\begin{array}{l}\text { very } \\
\text { import }\end{array}$ & 3.64 & 3.70 & 3.55 \\
\hline 2 & $\begin{array}{l}\text { Relationship with Top } \\
\text { Management }\end{array}$ & ant & 3.53 & 3.43 & 3.57 \\
\hline 3 & $\begin{array}{l}\text { Networking with } \\
\text { clients }\end{array}$ & & 3.51 & 3.74 & 3.28 \\
\hline 4 & $\begin{array}{l}\text { Networking with } \\
\text { journalists }\end{array}$ & & 3.47 & 3.67 & 3.3 \\
\hline 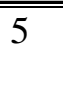 & $\begin{array}{l}\text { Networking with } \\
\text { colleagues }\end{array}$ & $\begin{array}{l}\text { quite } \\
\text { import }\end{array}$ & 3.36 & 3.36 & 3.31 \\
\hline 6 & Networking with peers & ant & 3.27 & 3.33 & 3.21 \\
\hline 7 & $\begin{array}{l}\text { Personal interest in } \\
\text { core business area }\end{array}$ & & 3.18 & 3.17 & 3.18 \\
\hline 8 & $\begin{array}{l}\text { Continuous } \\
\text { professional } \\
\text { development }\end{array}$ & & 2.97 & 3.04 & 2.92 \\
\hline 9 & $\begin{array}{l}\text { Hard work \& out of } \\
\text { office hours }\end{array}$ & & 2.94 & 2.97 & 2.84 \\
\hline 10 & $\begin{array}{l}\text { Structured company } \\
\text { training programme }\end{array}$ & & 2.89 & 2.94 & 2.9 \\
\hline 11 & Years of experience & & 3.81 & 2.87 & 2.72 \\
\hline 12 & $\begin{array}{l}\text { Membership in } \\
\text { industry association }\end{array}$ & & 2.77 & 2.67 & 2.82 \\
\hline 13 & $\begin{array}{l}\text { Visiting seminars \& } \\
\text { workshops }\end{array}$ & & 2.75 & 2.77 & 2.76 \\
\hline 14 & Professional mentor & & 2.73 & 2.84 & 2.68 \\
\hline 15 & $\begin{array}{l}\text { Relevant Marketing or } \\
\text { PR qualification }\end{array}$ & & 2.67 & 2.57 & 2.79 \\
\hline 16 & $\begin{array}{l}\text { Involvement in PR } \\
\text { industry events }\end{array}$ & & 2.51 & 2.47 & 2.51 \\
\hline 17 & $\begin{array}{l}\text { Changing companies } \\
\text { frequently }\end{array}$ & neutral & 1.87 & 1.71 & 1.96 \\
\hline 18 & Gender & & 1.83 & 1.28 & 1.26 \\
\hline
\end{tabular}

Overall, consultancy practitioners placed slightly more emphasis on social factors, such as strong personality and enthusiasm, networking with journalists and clients and the consideration of friends, colleagues and company culture when moving positions. The findings from the sample 
thereby agreed with those of PR scholars, who stated that teamwork was particularly emphasised in consultancies (e.g. Cutlip et al., 2005). Due to their close working relationships respondents stated that the right personality was often more important than formal qualifications: "It is about personality in public relations. You can be the nicest person in the world, but working in agencies is very intensive and you spend a lot of time together. So if you do not fit in, you won't get on". A senior practitioner further explained that "we have had people who worked for us in the past, who had PR degrees but haven't had that 'umpf' about them.... If they are too quiet or serious you think: how are they going to handle clients? [..] I think you have to be really confident and outgoing to succeed in this industry".

In-house practitioners commented on frequently limited job opportunities, not only within their own companies but also within their particular sector, or area of expertise. As professionals specialise in certain business areas, such as aviation, education or the arts, they tend to socialise and change position within these sub-networks, rather than looking at the total of in-house positions available. Being frequently restricted to a small or micro-sized department, in-house practitioners particularly emphasised the importance of their relationship to top management, both as consideration when moving companies, as well as for their overall career advancement. Two dominant themes emerged from the qualitative responses: The necessity of a supportive top management team to realise personal career advancement opportunities, as well as the required appreciation of public relations as a management rather than a publicity function:

"Make sure that the organisation which you join [...] is making sure that recognition is there for the role that PR can play. I think there is an increasing understanding at board level about the role of PR. But I think that still too many people see it as producing press releases," stated one respondent. Another further explained: "Your advancement depends to some extent on how 
senior managers perceive and experience the benefits of good PR/communications in their organization”.

However, the findings from this sample indicate that both career paths are interrelated, thereby confirming a trend of practitioners moving from consultancies to in-house departments, but rarely vice versa. While consultancy work was referred to as "an opportunity to gain a wide range of experience", practitioners were drawn to in-house positions by the opportunity to work more strategically, project focused, and "during 'regular' hours". One respondent went as far as to refer to in-house positions as the holy grail for consultancy practitioners: "Probably because inhouse you get more structure and are part of the company culture”, she explained.

\section{Steeper steps}

Wolf's (2006) findings indicated that compared to Morgan's (2002) management-focused Building Blocks, the “'steps' leading up the PR Career Ladder appear to be smaller, and practitioners consequently may progress faster than general management employees" (p. 183). While Morgan's Building Blocks covered a 4-5 year period, PR practitioners in the 2006 study only spend an average of two to three years on each level before moving up. However, a comparison between the two key employment options indicates that steps on the consultancy career ladder may be even steeper (Table 2). While their in-house counterparts reportedly spend an average of 1.9 years in each position, consultancy based practitioners spend a slightly longer average of 2.2 years in each job. However, particularly during the first years of their career, they appear to move up to the next level with more ease.

Fast track opportunities for high achievers? 
Table 2: Average time spent working on each level/in each position (in years)

\begin{tabular}{|l|l|l|l|}
\hline & $\begin{array}{l}\text { Original } \\
\text { Overall } \\
\text { Mean }\end{array}$ & $\begin{array}{l}\text { In-house } \\
\text { Mean }\end{array}$ & $\begin{array}{l}\text { Consultancy } \\
\text { Mean }\end{array}$ \\
\hline Level I & 1.6 & 2.1 & 1.1 \\
\hline Level II & 2.4 & 2.6 & 1.8 \\
\hline Level III & 3 & 2.7 & 2.8 \\
\hline Level IV & 4.4 & 5.5 & 4.4 \\
\hline In each & 2.2 & 1.9 & 2.2 \\
position & & & \\
\hline
\end{tabular}

their own department/company and the industry sub-section they are working in. It furthermore indicates that each change of position may not automatically result in a move to the next higher career level. However, despite the professionalisation of the PR industry and increasingly higher expectations (Ishida et al., 2002; Morgan, 2002), confirming that experience is no longer measured in time, but in output, which ultimately provides fast track opportunities for high achievers:

"Advancement in PR is significantly and primarily about attitude of mind and enthusiasm”, wrote one respondent. A consultancy-based employer further explained: "Nothing influences our employees' career advancement more than 'relevant' hard work (not out of hours but specific to the role) and attitude/ enthusiasm, combined with determination to get results". 


\section{Conclusion}

The scope of this study is evidently limited, due to its focus on the UK's public relations industry. However, by focusing on one of the world's arguably most developed and recognised industries - in terms of visibility, membership, research, education and history - this study may inform other geographical areas and additionally provide a platform for further research into (global) career advancement factors and patterns. The growing focus on the professionalisation of the public relations industry is putting increased pressure on industry bodies to join forces, cooperate and develop globally recognised guidelines and codes of conduct. The Public Relations Institute of Australia is a key member of the Global Alliance for public relations and communication management, which through its associations represents over 160,000 PR and communication practitioners across the world. Furthermore, with an emphasised importance on internationalising higher education curricula and an increasingly global market place, more Australian PR graduates are venturing overseas to gain valuable work experience as well as to gain first hand experience of different cultures.

Public relations and communication graduates around the globe continue to debate the pro and cons of the industry's two key employment options. However, to date scholarly research into career advancement patters has been largely restricted to in-house practitioners and focused on outdated determinants. This study indicates that perceptions of career advancement for both employment groups are broadly in line. However, the existence of a clearer and better outlined career route for consultancy professionals has become apparent. Professional titles, responsibilities and consequently pay scales appear to become increasingly transparent and (globally) accepted for PR consultants. In contrast to this, in-house communicators frequently 
find themselves restricted by the small or micro size of their department and a wide array of arbitrary, often individually tailored, titles. This plethora of job titles was recently confirmed by a nationwide study into the Australian public relations industry, which reported 171 title variations amongst a total of 323 respondents (Wolf \& De Bussy, 2008). Nevertheless, both types of employment appear to be interrelated, with consultancy practitioners moving in-house, but rarely vice versa. While alternative factors such as enthusiasm and networking skills are less objective to judge than traditional measures such as years of experience, they are nevertheless increasingly recognised as career advancement determinants by industry representatives.

Further research will be required to confirm alternative factors and advancement trends as well as their applicability to other geographical areas. Additionally, comparative studies with related industries, such as marketing and advertising, as well as into traditional professions and trades, would provide further insight into PR industry specific factors, as well as highlight general trends in career advancement. 


\section{References}

Broom, G. M., \& Smith, G. D. (1979). Testing the practitioner's impact on clients. Public Relations Review, 5(3), 47-59.

Burns, R. (2002). The Adult Learner at Work (2nd ed.). Crows Nest: Allen \& Unwin.

Cappelli, P. (2003). Career Jobs Are Dead. Benefits for the Workplace of the Future.

Chartered Institute of Public Relations. (2008). Careers \& Education. Retrieved 15th June 2008, from http://www.cipr.co.uk/direct/careers.asp?v1=whatis

Coppola, P. (2003). Advertising \& Public Relations sector. Agcas.

Cutlip, S. M., Center, A. H., \& Broom, G. M. (2005). Effective Public Relations (9th ed.): Prentice Hall.

DeSanto, B., \& Moss, D. (2004). Rediscovering what PR managers do: Rethinking the measurement of managerial behaviour in the public relations context. Journal of Communication Management, 9(2), 179-196.

Dozier, D. M. (1984). Program evaluation and roles of practitioners. Public Relations Review, $10(2), 13-21$.

Dozier, D. M., \& Broom, G. M. (1995). Evolution of the Manager Role in Public Relations Practice. Journal of Public Relations Research, 7(1), 3-26.

Ehling, W. P. (1992). Public relations education and professionalism. In J. E. Grunig (Ed.), Excellence in public relations and communication management (pp. 439-464). Hillsdale, N.J.

Forsyth, P. (1998). Career Skills: A Guide to Long-Term Success: Cassell.

Gow, K., \& McDonald, P. (2000). Attributes required of graduates for the future workplace. Journal of Vocational Education and Training, 52(3), 373-396. 
Grunig, J. E., \& Repper, F. C. (1992). Strategic management, publics, and issues. In J. E. Grunig (Ed.), Excellence in public relations and communication management (pp. 117-157): Lawrence Erlbaum Associates.

Holbeche, L. (2005). Understanding Change: Theory, Implementation and Success: ButterworthHeinemann.

Ishida, H., Su, K. H., \& Spilerman, S. (2002). Models of Career Advancement in Organizations. European Sociological Review, 18(2), 179-198.

James, M. (2006). Public Relations - real jobs, real people, real experience: Career FAQs Pty Ltd.

Keaveney, J. (2004). Advertising, public relations and direct marketing: Agcas.

Khare, S. (2007, 16 April 2007). Career Directions for the Generation Y - the Newcomers to the Workplace Retrieved 12 March 2008, from http://careerbright.blogspot.com/2007/04/career-directions-for-generation-y.html

Lips-Wiersma, M., \& Hall, D. T. (2007). Organizational career development is not dead: a case study on managing the new career during organizational change. JOURNAL OF ORGANIZATIONAL BEHAVIOR, 28(6), 771.

Morgan, M. (2002). Career-building strategies. Government Finance Review, 18(6), 14-16.

Moss, D., \& Green, R. (2001). Re-examining the manager's role in public relations: what management and public relations research teaches us. Journal of Communication Management, 6(2), 118-133.

Moss, D., Newman, A. J., \& DeSanto, B. (2005). What do Communication Managers do? Defining and refining the core elements of management in a public relations/ corporate communication context. Journalism and Mass Communication Quarterly, 82(4), 873-890. 
Moss, D., Warnaby, G., \& Newman, A. J. (2000). Public Relations Practitioner Role Enactment at the Senior Management Level Within UK Companies. Journal of Public Relations Research, 12(4), 277-307.

Newsom, D., Turk, J. V., \& Kruckenberg, D. (2007). This is PR - The realities of public relations (9th ed.): Thomson Wadsworth.

Pieczka, M., \& L'Etang, J. (2006). Public Relations and the question of professionalism. In J. L'Etang \& M. Pieczka (Eds.), Public Relations: Critical Debates and Contemporary Practice (pp. pp. 265-278). Mahwah, N.J.: Lawrence Erlbaum Associates.

Sahdev, K., Vinnicombe, S., \& Tyson, S. (1999). Downsizing and the changing role of HR. The International Journal of Human Resource Management, 10(5), 906-923.

Singh, R., \& Smyth, R. (2000). Australian public relations: status at the turn of the 21st century. Public Relations Review, 26(4), 387-401.

Toth, E. L., Serini, S. A., Wright, D. K., \& Emig, A. G. (1998). Trends in public relations roles: 1990-1995. Public Relations Review, 24(2), 145-163.

Valin, J. (2005). One profession - one voice - public relations around the world. Remarks by Jean Valin, APR, Fellow CPRS, Chair of the Global Alliance. Paper presented at the All India Conference, New Delhi.

Van Ruler, B. (2005). Commentary: Professionals are from Venus, scholars are from Mars. Public Relations Review, 31(2), 159-173.

White, J., \& Dozier, D. M. (1992). Public relations and management decision making. In J. E. Grunig (Ed.), Excellence in public relations and communication management (pp. 91108): Lawrence Erlbaum Associates.

Wolf, K. (2006). PR career progression-the gap between traditional research and the UK industry’s perception. Journal of Communication Management, 10(2), 174-190. 
Wolf, K., \& De Bussy, N. (2008). Perceptions of professionalism: Practitioner reflections on the state of Australian public relations. Paper presented at the 2008 National PRIA Conference.

Wylie, F. (1994). Commentary: Public relations is not yet a profession. Public Relations Review, $20(1), 1-3$. 